\title{
Sorghum Malt Extract as a Growth Medium for Lactic Acid Bacteria Cultures: A Case of Lactobacillus plantarum MNC 21
}

\author{
Stellah Byakika (D), Ivan Muzira Mukisa $(\mathbb{D}$, and Yusuf Byenkya Byaruhanga $(\mathbb{D}$ \\ Department of Food Technology and Nutrition, School of Food Technology Nutrition and Bioengineering, \\ College of Agricultural and Environmental Sciences, Makerere University, P.O. Box 7062, Kampala, Uganda
}

Correspondence should be addressed to Yusuf Byenkya Byaruhanga; ybbyaru@gmail.com

Received 2 November 2020; Accepted 3 December 2020; Published 11 December 2020

Academic Editor: Giuseppe Comi

Copyright $(92020$ Stellah Byakika et al. This is an open access article distributed under the Creative Commons Attribution License, which permits unrestricted use, distribution, and reproduction in any medium, provided the original work is properly cited.

Cultivation of lactic acid bacteria cultures is vital for research and commercial production of fermented foods. However, the conventional growth media used are generally costly. Malt extracts from four sorghum varieties (SESO 1, SESO 3, Epuripur, and Eyera) were evaluated as alternative low-cost growth media for Lactobacillus plantarum MNC 21. Saccharified sorghum malt extracts were inoculated with $4 \log \mathrm{cfu} / \mathrm{mL}$ MNC 21 and incubated at $30^{\circ} \mathrm{C}$ for $24 \mathrm{~h}$. MRS broth was the reference medium. Microbial counts, $\mathrm{pH}$, titratable acidity (TA), free amino nitrogen (FAN), and total sugars were measured. Maximum microbial counts in the extracts and MRS broth were 9 and $10 \log \mathrm{cfu} / \mathrm{mL}$, respectively. Maximum growth rate in the extracts was $0.7-0.9 \log$ $\mathrm{cfu} / \mathrm{mL} / \mathrm{h}$ and $0.8 \log \mathrm{cfu} / \mathrm{mL} / \mathrm{h}$ in MRS broth. The final $\mathrm{pH}$ of the extracts was 3.5-3.6, with an overall increase in TA of $1.2 \%$ in Epuripur and $0.2 \%$ in other varieties. Final $\mathrm{pH}$ and TA of MRS broth were 4.1 and $1.3 \%$, respectively. Total sugars dropped by 95.2\% and FAN by $2.1 \%$ in MRS broth. In contrast, total sugars and FAN dropped by $5.6-9.1 \%$ and $24.9-32.7 \%$ respectively, in the extracts. Sorghum malt extracts can be adopted as alternative low-cost growth media for lactic acid bacteria cultures.

\section{Introduction}

Lactic acid bacteria (LAB) are commonly applied as starter cultures for numerous fermented foods, cereals, tubers, fruits, vegetables, milk, fish, and meat. They impart characteristic flavors and tastes while contributing to food safety and preservation [1]. Some LAB strains such as Lactobacillus (L.) rhamnosus GG, L. plantarum 299v, and L. casei Shirota have probiotic properties such as alleviation of rotavirus diarrhea, prevention of traveller's diarrhea and Clostridium difficile colitis, prevention of atopic dermatitis, treatment of irritable bowel syndrome, increase in iron absorption, intestinal flora reposition, and improved digestion [2-5].

The growth of LAB is often restricted to rich-nutrient habitats, so they are cultivated in conventional media such as lactobacilli MRS broth, M17 broth, Micro Inoculum Broth, Rogosa SL Broth, Tomato Juice Broth, APT Broth, Elliker Broth, and Lactobacillus Selection Broth [6]. These media are costly owing to their composition and preparation, thus limiting their application to quality control, laboratory analysis, research, and academic uses [7]. So, it is important to develop alternative low-cost media for industrial applications like production of starter cultures and probiotics. Low-cost cultivation media from locally available materials such as mushrooms, tomatoes, corn, fish viscera hydrolysate, sweet potatoes, whey, buttermilk, pineapple peels, chick pea, cabbage, wheat, barley, and sugar beet molasses have been reported [8-18]. Sorghum is a low-cost cereal found in almost all parts of the world. It is mainly consumed as food and feed. Sorghum has not yet been exploited as a potential low-cost microbial cultivation medium, yet it can support growth of a diversity of LAB and yeasts in traditional fermentations $[19,20]$. In its malted form, sorghum has a nutrient profile that could support the luxurious growth of LAB [21]. So, sorghum malt extract could be used for microbial cultivation, but this had not been evaluated previously.

L. plantarum are generally regarded as safe owing to their documented history of safe use $[9,22]$. These LAB are thus widely used in food fermentation because of the sensory 
and shelf life qualities they render to food [22]. L. plantarum MNC 21, an isolate of Obushera, a fermented sorghummillet beverage from Uganda, is a high acid producer and acid-stable microbe. It is thus a suitable starter culture for Obushera [23]. It is fastidious, and its successful cultivation in a given medium could indicate the same for several other microbes. Therefore, this study evaluated sorghum malt extracts as cultivation media for L. plantarum MNC 21.

\section{Materials and Methods}

2.1. Sorghum. Four improved sorghum varieties (SESO 1, SESO 3, Epuripur, and Eyera) were used in this study. SESO 1 and Epuripur are white-grained, whereas SESO 3 is browngrained. Eyera is a popular local brown-grained variety. All four varieties were obtained from National Semi-Arid Resources Research Institute in Serere district, Uganda.

2.2. Sorghum Malt Extracts. Sorghum grain was malted following procedures described by Taylor [24]. The malted grain was milled using a Wonder Mill (110 Volt model, California, USA) and sieved using a $800 \mu \mathrm{m}$ screen. The flour was mixed with water to form a mixture of $11 \%$ total solids. To convert starch to maltose, the mixture was heated to $75^{\circ} \mathrm{C}$, followed by addition of $\alpha$-amylase (Anke Bio Engineering Company Limited, China) at a rate of 1000 units per $\mathrm{mL}$. The slurry was held at $75^{\circ} \mathrm{C}$ for $1 \mathrm{~h}$ with continuous stirring. To convert maltose to glucose, the slurry temperature was lowered to $55^{\circ} \mathrm{C}$, and amyloglucosidase (Anke Bio Engineering Company Limited, China) was added at a rate of 1000 units per mL. The slurry was held at $55^{\circ} \mathrm{C}$ for $1 \mathrm{~h}$ with continuous stirring. The malt extract was cooled to about $25^{\circ} \mathrm{C}$, decanted, and filtered using grade filter papers (Whatman No. 1). It was then sterilized at $121^{\circ} \mathrm{C}$ for $15 \mathrm{~min}$ and cooled to $25^{\circ} \mathrm{C}$.

2.3. Microbial Culture. L. plantarum MNC 21 isolated from Obushera by Mukisa [23] was used. From the stock culture, $0.1 \mathrm{~mL}$ was delivered into $100 \mathrm{~mL}$ of sterile MRS broth (CONDA, Madrid, Spain) and incubated at $30^{\circ} \mathrm{C}$ for $24 \mathrm{~h}$. L. plantarum MNC 21 was subcultured thrice after which the cells were recovered by centrifugation at 7,500 $\mathrm{x} g$ for $10 \mathrm{~min}$. The cell pellets were suspended in $10 \mathrm{~mL}$ of sterile Ringer's solution. Culture purity was checked using a microscope (020-518.500 DM/LS I/98 model, Leica, Germany).

2.4. Propagation of L. plantarum MNC 21 in Sorghum Malt Extract. A hundred milliliters of sterile sorghum malt extract were inoculated with about $4 \log \mathrm{cfu} / \mathrm{mL}$ of L. plantarum MNC 21 and incubated at $30^{\circ} \mathrm{C}$ for $24 \mathrm{~h}$. Growth characteristics of MNC 21 were evaluated by determining microbial counts, $\mathrm{pH}$, titratable acidity (TA), total sugars, and free amino nitrogen (FAN) at $2 \mathrm{~h}$ intervals for $24 \mathrm{~h}$. MRS broth was also inoculated with MNC 21 and used as the control medium. The maximum growth rate $\left(\mu_{\max }\right)$ was calculated as described by [25].
2.5. Analyses. Microbial counts were determined by pour plating selected serial dilutions of the malt extract or MRS broth containing L. plantarum MNC 21 in MRS agar and incubating at $30^{\circ} \mathrm{C}$ for $48 \mathrm{~h}$. The $\mathrm{pH}$ was determined using a pH meter (AG model, Mettler-Toledo Group, Switzerland). Titratable acidity was determined by titrating $10 \mathrm{~mL}$ of the extract against $0.1 \mathrm{~N} \mathrm{NaOH}$ using phenolphthalein indicator [26]. FAN was determined using the Ninhydrin method [27]. Total sugars were determined using the Phenol-Sulfuric acid method [28].

2.6. Statistical Analyses. Results were presented as mean$\mathrm{s} \pm$ standard deviations (mean $\pm \mathrm{SD}$ ) of three independent experiments. Data were subjected to one-way analysis of variance (ANOVA) to test for significant differences at $\alpha=0.05$. Mean comparisons were made using the least significant difference (LSD) test. Analyses were done using Statistix (student version 9.0) software.

\section{Results and Discussion}

3.1. Growth Characteristics of L. plantarum MNC 21. Figure 1 and Table 1 summarize the growth characteristics of L. plantarum MNC 21 in MRS broth and malt extracts from different sorghum varieties. The LAB grew in all varieties, reaching a maximum average microbial count of $8.9 \pm 0.0 \mathrm{log}$ $\mathrm{cfu} / \mathrm{mL}$, one log cycle lower than what was observed in MRS broth. A steep increase in microbial counts in all media occurred in the first $4-18 \mathrm{~h}$ of fermentation and then plateaued. Maximum microbial counts were obtained earliest (16 h) in Epuripur and latest in MRS broth (22 h). Maximum growth rate $\left(\mu_{\max }\right)$ was in the order Epuripur $>$ SESO $1=$ MRS broth $>$ SESO $3=$ Eyera (Table 1 ). The net increase in microbial counts at $24 \mathrm{~h}$ was in the order MRS broth $(6.2$ $\log \mathrm{cfu} / \mathrm{mL})>$ Eyera $(5.1 \log \mathrm{cfu} / \mathrm{mL})=$ SESO $3(5.1 \log \mathrm{cfu} /$ $\mathrm{mL})>$ SESO $1=(4.8 \log \mathrm{cfu} / \mathrm{mL})>$ Epuripur $(4.9 \log \mathrm{cfu} /$ $\mathrm{mL})$.

Values are means \pm standard deviations. Values in the same column with similar superscripts are not significantly different $(p>0.05) . \quad X_{0}=$ Initial microbial count, $X_{\max }=$ maximum microbial count, and $\mu_{\max }$ growth rate constant.

The maximal cell concentration of lactobacilli reported in a static $\mathrm{pH}$ (6.5) bioreactor using a corn steep liquor medium is $10 \log \mathrm{cfu} / \mathrm{mL}$ [29]. This is equivalent to the maximal growth observed in this study for MRS broth. The significantly high microbial counts in MRS broth, especially after $18 \mathrm{~h}$, could be explained by the fact that MRS broth is specially developed for the luxurious growth of fastidious Lactobacillus spp. [9]. The broth is buffered and highly enriched with nitrogen sources; bacteriological peptone $(10 \mathrm{~g} / \mathrm{L})$, yeast extract $(4 \mathrm{~g} / \mathrm{L})$, and beef extract $(8 \mathrm{~g} / \mathrm{L})$ are important for biomass synthesis [30, 31]. The maximal microbial growth observed in sorghum malt extracts in this study agrees with values reported by Muyanja et al. [19] and Mukisa [23]. These authors reported the ability of L. plantarum to grow to $9 \log \mathrm{cfu} / \mathrm{mL}$ after $24 \mathrm{~h}$ of 


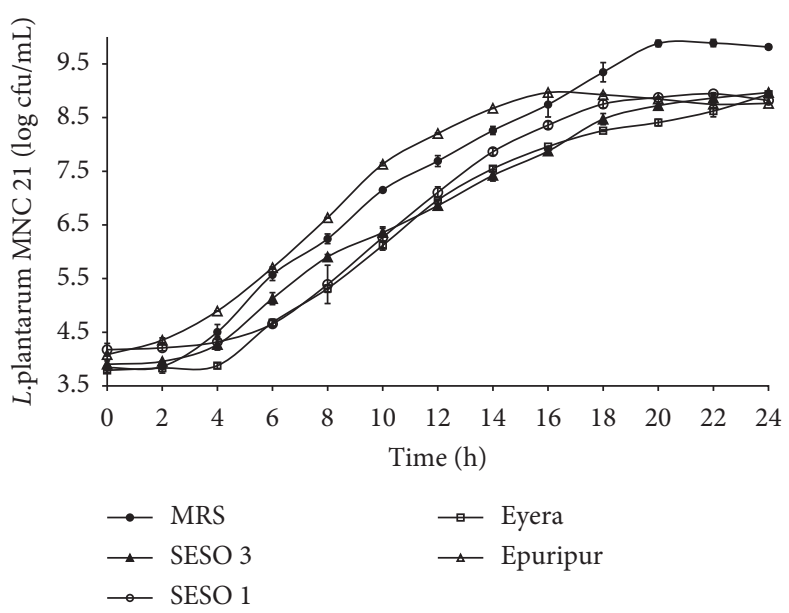

Figure 1: Growth profiles of L. plantarum MNC 21 in MRS broth and malt extracts from different sorghum varieties. Error bars show standard deviations of three independent fermentations.

TABLE 1: L. plantarum MNC 21 growth parameters in MRS broth and sorghum malt extracts.

\begin{tabular}{lcccc}
\hline Growth medium & $X_{0}(\log \mathrm{cfu} / \mathrm{mL})$ & $X_{\max }(\log \mathrm{cfu} / \mathrm{mL})$ & Time $(h)$ at $X_{\max }$ & $\mu_{\max }(\log \mathrm{cfu} / \mathrm{ml} / \mathrm{h})$ \\
\hline MRS broth & $3.8^{\mathrm{bc}} \pm 0.0$ & $10.0^{\mathrm{a}} \pm 0.0$ & 22 & $0.8^{\mathrm{b}} \pm 0.0$ \\
SESO 1 & $4.1^{\mathrm{bc}} \pm 0.1$ & $8.9^{\mathrm{b}} \pm 0.0$ & 22 & $0.8^{\mathrm{b}} \pm 0.0$ \\
SESO 3 & $3.9^{\mathrm{b}} \pm 0.1$ & $9.0^{\mathrm{b}} \pm 0.0$ & 24 & $0.7^{\mathrm{c}} \pm 0.0$ \\
Epuripur & $4.1^{\mathrm{a}} \pm 0.0$ & $9.0^{\mathrm{b}} \pm 0.0$ & 16 & $0.9^{\mathrm{a}} \pm 0.0$ \\
Eyera & $3.8^{\mathrm{c}} \pm 0.0$ & $8.9^{\mathrm{b}} \pm 0.0$ & 24 & $0.7^{\mathrm{d}} \pm 0.0$ \\
\hline
\end{tabular}

fermentation. The maximum growth observed in the malt extract was also in agreement with Saman et al. [32], who used rice media to grow L. plantarum NCIMB 8826. Growth of L. plantarum MNC 21 to a lower concentration than observed for MRS broth was probably due to toxicity from lactic acid accumulation [29, 33]. Therefore, maximal microbial biomass growth in sorghum malt extracts could be increased by addition of buffers.

The increase in microbial counts per mg FAN utilized was lower in the sorghum malt extracts $(0.2-0.3 \log \mathrm{cfu} / \mathrm{mg}$ FAN) than in MRS broth (1.5 log cfu/mg FAN). MRS broth has yeast extract, beef extract, and bacteriological peptone which could be more superior nitrogen sources than the sorghum protein. Therefore, the lower $(P<0.05)$ maximum cell counts obtained in the malt extracts could be attributed to the low quality rather than quantity of FAN in the malt extracts since the residual FAN in the broth and malt extracts was still high at the end of the fermentation (Figure 2). Thomas and Ingledew [34] reported a relationship between the quality of FAN and rate of sugar utilization by microorganisms. Higher utilization of sugar by Saccharomyces cerevisiae and higher biomass production were reported when the growth medium was supplemented with glutamic acid. However, when replaced with glycine as the major source of FAN, a low sugar utilization and small increase in growth were observed. Therefore, the higher utilization of total sugars in MRS broth could be attributed to the better quality of FAN in MRS broth. Saguir et al. [35] observed glucose utilization and biomass production of L. plantarum $\mathrm{N} 4$ to be associated with the chain length of amino acids. They noted that addition of dipeptides to growth media

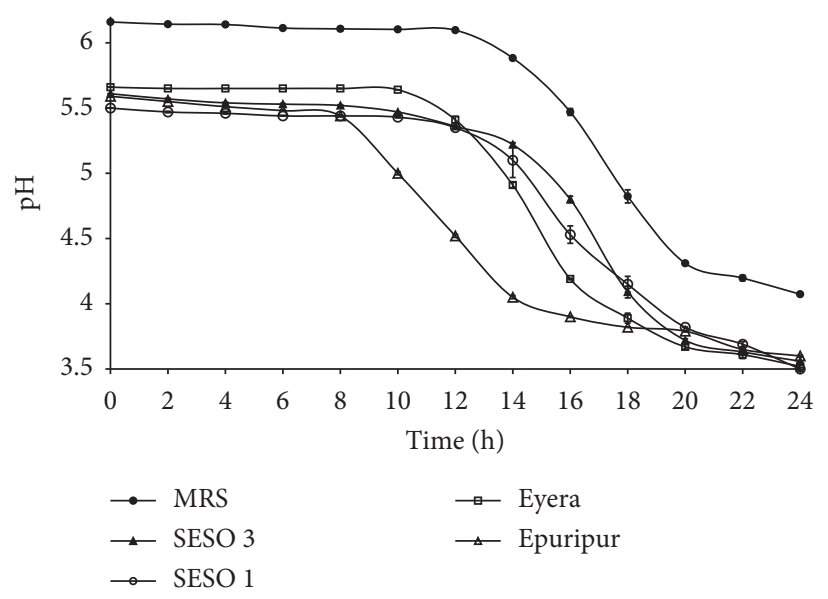

FIGURE 2: Free amino nitrogen utilization by L. plantarum MNC 21 in MRS broth and malt extracts from different sorghum varieties. Error bars show standard deviations of three independent fermentations.

increased both sugar utilization and biomass production. Inclusion of free amino acids to the growth media did not increase sugar utilization and biomass production as much as the respective dipeptides. Therefore, growth of microbial biomass in sorghum malt extracts could be improved by selective addition of growth promoting FAN sources.

Although the final cell concentration attained in the sorghum malt extracts was similar, Epuripur would be preferred for biomass production. This is because L. plantarum MNC 21 not only exhibited the highest $(P<0.05)$ growth rate but also 
attained its maximum cell count 6-8 h earlier than the rest of the varieties (Table 1). Statistical analysis indicated varietal differences in the total sugars and FAN levels despite the small ranges. Therefore, the better performance of Epuripur could be attributed to its high endogenous enzyme activity. Epuripur is specifically bred for brewing and possesses high amylolytic activity [36]. It could also possibly have high proteolytic activity resulting in a better nitrogen profile than the other varieties. In a previous study, Epuripur had the highest free amino nitrogen probably resulting from higher proteolytic activity [21].

3.2. $\mathrm{pH}$ and Acidity. The trends in $\mathrm{pH}$ and $\mathrm{TA}$ in the media are shown in Figures 3 and 4, respectively. There was a significant drop in the $\mathrm{pH}$ of all media from the start to the end of the fermentation (Figure 3). The $\mathrm{pH}$ dropped from 6.2 to 4.1 in MRS broth and from 5.5-5.6 to 3.5-3.6 in the malt extracts. The sharpest $\mathrm{pH}$ drop was observed in the first $16-18 \mathrm{~h}$ of fermentation. Among the sorghum varieties, the fastest $\mathrm{pH}$ drop was in Epuripur which attained $\mathrm{pH}=4.0$ in approximately $12 \mathrm{~h}$ of fermentation. This was followed by Eyera, SESO 1, SESO 3, and MRS broth. The increases in TA were concomitant with the $\mathrm{pH}$ reductions (Figures 3 and 4). The highest increase in TA was $1.3 \%$ in MRS broth, followed by $1.2 \%$ in Epuripur and $0.2 \%$ in the rest of the varieties. Rapid acid production was observed between 12 and $24 \mathrm{~h}$ of fermentation.

The changes in $\mathrm{pH}$ observed in this study are in agreement with values reported for different acid-fermented foods: sorghum and millet [19, 23]), rice [32], wheat [37], and cassava $[38,39]$. The $\mathrm{pH}$ drop results from conversion of sugars to lactic acid by L. plantarum MNC 21 . The exponential growth phase (Figure 1) coincided with the sharp drop in $\mathrm{pH}$ and a corresponding sharp increase in \% TA (Figure 4). Although the highest cell production was observed in MRS broth (Figure 1), this broth had the highest $\mathrm{pH}$ (Figure 3). This is attributed to potassium phosphate which buffers the MRS broth [40]. On the other hand, the buffering system in sorghum contributed by protein and ash is relatively weak [41]. Charalampopoulos et al. [8], in a similar study, proposed supplementation of barley malt medium with additives that enhance its buffering capacity so as to reduce acidification rates and increase fermentation times. This is especially important that when microbial growth is done in a batch system, alternatively a continuous system should be used. The estimated lowest $\mathrm{pH}$ for the growth of L. plantarum is 3.4 [8, 42]. Indeed, the growth rate of L. plantarum MNC 21 kept dropping as $\mathrm{pH}$ approached 3.4. Extreme low $\mathrm{pH}$ conditions cause the undissociated organic acids to penetrate microbial cells and dissociate within the cytoplasm. This alters cytoplasmic $\mathrm{pH}$, hampers normal cellular function, and eventually causes death [43]. Among the varieties, Epuripur had the biggest increase in TA coupled with the highest $\mathrm{pH}$ at the end of the fermentation (Figures 3 and 4) possibly implying that it had the best buffering system. Of all the four sorghum varieties used in this study Epuripur in fact has the highest FAN levels [21] suggesting that it could have the highest buffering capacity.

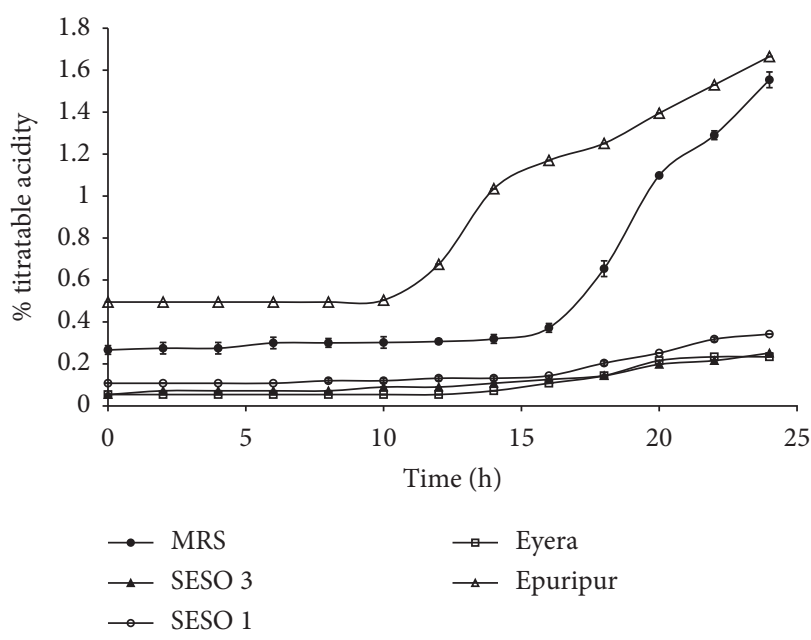

FIGURE 3: Changes in $\mathrm{pH}$ during growth of L. plantarum MNC 21 in MRS broth and malt extracts from different sorghum varieties. Error bars show standard deviations of three independent fermentations.

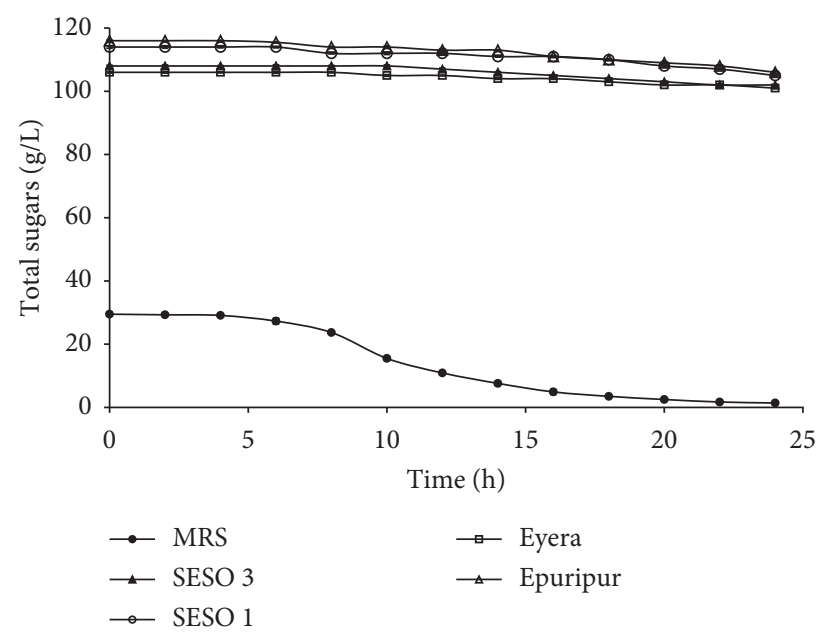

FIgURE 4: Changes in titratable acidity during growth of L. plantarum MNC 21 in MRS broth and malt extracts from different sorghum varieties. Error bars show standard deviations of three independent fermentations.

\section{Total Sugars and FAN}

The changes in total sugars (calculated as glucose equivalents) and FAN in the media are shown in Figures 2 and 5, respectively. Initial total sugars in MRS broth were about five times lower than in the malt extracts. A sharp decrease in total sugars occurred after about $8 \mathrm{~h}$ of fermentation. The overall decrease in total sugars was $95.3 \%$ in MRS broth and $5.0-9.1 \%$ in the malt extracts. The rate of sugar utilization in MRS broth was higher than in the malt extracts (Table 2). The initial FAN levels of the malt extracts were about three times lower than those in MRS broth. FAN in MRS broth and the sorghum malt extracts decreased by $2.1 \%$ and 24.9-32.7\%, respectively. The largest decrease in FAN in the malt extracts occurred in the first $10 \mathrm{~h}$ of fermentation. The 


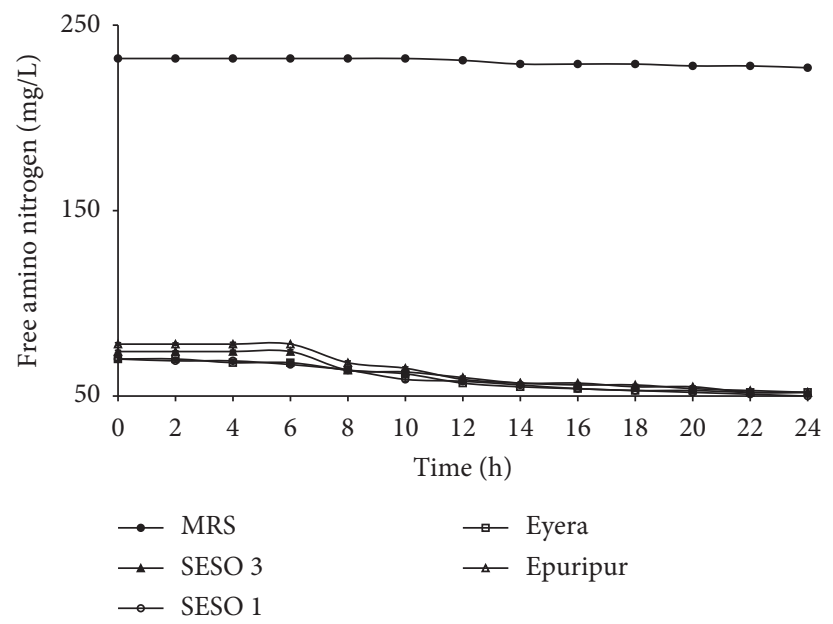

FIgURE 5: Reduction in total sugars during growth of L. plantarum MNC 21 in MRS broth and malt extracts from different sorghum varieties. Error bars show standard deviations of three independent fermentations.

TABLE 2: Overall utilization of free amino nitrogen and total sugars by L. plantarum MNC 21 after $24 \mathrm{~h}\left(30^{\circ} \mathrm{C}\right)$ in $\mathrm{MRS}$ broth and malt extracts from different sorghum varieties.

\begin{tabular}{|c|c|c|c|c|}
\hline \multirow{2}{*}{ Media } & \multicolumn{2}{|c|}{ Rates of decrease in log phase } & \multicolumn{2}{|c|}{ Overall utilization (\%) } \\
\hline & Free amino nitrogen $(\mathrm{mg} / \mathrm{L} / \mathrm{h})$ & Total sugars $(\mathrm{g} / \mathrm{L} / \mathrm{h})$ & Free amino nitrogen & Total sugars \\
\hline MRS broth & $0.3^{\mathrm{b}} \pm 0.1$ & $1.5^{\mathrm{a}} \pm 0.1$ & $2.1^{\mathrm{d}} \pm 0.4$ & $95.3^{\mathrm{a}} \pm 0.7$ \\
\hline SESO 1 & $1.1^{\mathrm{a}} \pm 0.1$ & $0.3^{\mathrm{b}} \pm 0.0$ & $29.4^{\mathrm{b}} \pm 1.2$ & $8.2^{\mathrm{b}} \pm 0.3$ \\
\hline SESO 3 & $1.1^{\mathrm{a}} \pm 0.0$ & $0.3^{\mathrm{b}} \pm 0.1$ & $31.2^{\mathrm{a}} \pm 0.8$ & $5.6^{\mathrm{c}} \pm 0.7$ \\
\hline Epuripur & $1.4^{\mathrm{a}} \pm 0.0$ & $0.3^{\mathrm{b}} \pm 0.0$ & $32.7^{\mathrm{a}} \pm 0.6$ & $9.1^{\mathrm{b}} \pm 0.1$ \\
\hline Eyera & $0.9^{\mathrm{a}} \pm 0.0$ & $0.3^{\mathrm{b}} \pm 0.1$ & $24.9^{c} \pm 1.1$ & $5.0^{c} \pm 0.5$ \\
\hline
\end{tabular}

rate of decrease in FAN was higher in the malt extracts than in MRS broth (Table 2).

Values are means \pm standard deviations. Values in the same column with similar superscript letters are not significantly different $(P>0.05)$.

During growth, L. plantarum metabolizes glucose to produce primarily lactic acid, and the energy produced is largely used for cell division and maintenance [43]. This conversion results in depletion of sugars with a subsequent increase in \%TA. In this study, the malt extracts had much higher sugar levels than MRS broth, but the former had a smaller overall increase $(0.2 \%)$ in \% TA than MRS broth $(1.3 \%)$. This is may be due to lower sugar utilization in the malt extracts than in MRS (Table 2). Despite the low initial total sugars levels in MRS broth, it produced the highest $(P<0.05)$ cell counts by the end of the fermentation (Figure 1). Therefore, the total sugars in the malt extracts are far in excess and would not be a major limiting factor for growth of L. plantarum MNC 21 in the extracts is not.

Although the final microbial count in the extracts was about $9 \log \mathrm{cfu} / \mathrm{mL}$, one $\log$ lower $(P<0.05)$ than that attained in MRS broth (Figure 1), there was less FAN utilization in the MRS broth than in the malt extracts (Table 2). Unlike the malt extracts, MRS broth contains yeast extract, bacteriological peptone, and beef extracts which are rich nitrogen sources. Therefore, very little of these rich sources of FAN in the MRS are required to cause a significant increase in microbial growth. MRS was originally designed to support growth of the most fastidious LAB [9]. Therefore, it may contain excess nutrients when used for less nutrient demanding species such as some lactobacilli.

This study showed that sorghum malt extracts can be used as alternative growth medium for propagation of L. plantarum MNC 21 and possibly other microbial cultures. The carbon and nitrogen sources in the sorghum malt extracts are present in amounts sufficient to support growth of L. plantarum MNC 21. Performance of the sorghum malt extracts could be improved by addition of buffers to minimize the toxicity resulting from lactic acid accumulation.

\section{Data Availability}

The data in tables and figures used to support the findings of this study are included within the article.

\section{Conflicts of Interest}

The authors declare that they have no conflicts of interest.

\section{Acknowledgments}

This work was funded by the Association for Strengthening Agricultural Research in Eastern and Central Africa (ASARECA) under Grant ASARECA/AB/2012/02-2/D. The authors thank Mr. Ceasar Nsubuga for his technical assistance in preparation of the sorghum malt extracts. 


\section{References}

[1] T. Bintsis, "Lactic acid bacteria: their applications in foods," Journal of Bacteriology and Mycology, vol. 6, pp. 89-94, 2018.

[2] J. A. Drisko, C. K. Giles, and B. J. Bischoff, "Probiotics in health maintenance and disease prevention," Alternative Medicine Review, vol. 8, pp. 143-155, 2003.

[3] K. Matsumoto, T. Takada, K. Shimizu et al., "The effects of a probiotic milk product containing Lactobacillus casei strain Shirota on the defecation frequency and the intestinal microflora of sub-optimal health state volunteers: a randomized placebo-controlled cross-over study," Bioscience and Microflora, vol. 25, no. 2, pp. 39-48, 2006.

[4] P. Takada, P. Sawant, and V. Jayanthi, "Clinical trial:Lactobacillus plantarum299v (DSM 9843) improves symptoms of irritable bowel syndrome," World Journal of Gastroenterology, vol. 18, no. 30, p. 4012, 2012.

[5] R. Kort, G. Reid, L. Basten et al., "A novel consortium of Lactobacillus rhamnosus and Streptococcus thermophilus for increased access to functional fermented foods," Microbial Cell Factories, vol. 14, p. 195, 2015.

[6] M. Zimbro, D. Power, S. Miller, G. Wilson, and J. Johnson, Difco \& BBL Manual: Manual of Microbiological Culture Media, Becton. Becton, Dickinson and Company, Sparks, Maryland, 2003.

[7] S. A. Hayek, R. Gyawali, S. O. Aljaloud, A. Krastanov, and S. A. Ibrahim, "Cultivation media for lactic acid bacteria used in dairy products," Journal of Dairy Research, vol. 86, no. 4, pp. 490-502, 2019.

[8] D. Charalampopoulos, S. S. Pandiella, and C. Webb, "Growth studies of potentially probiotic lactic acid bacteria in cerealbased substrates," Journal of Applied Microbiology, vol. 92, no. 5, pp. 851-859, 2002.

[9] S. J. Horn, S. I. Aspmo, and V. G. H. Eijsink, "Growth of Lactobacillus plantarum in media containing hydrolysates of fish viscera," Journal of Applied Microbiology, vol. 99, no. 5, pp. 1082-1089, 2005.

[10] R. P. John, K. M. Nampoothiri, and A. Pandey, "Solid-state fermentation for L-lactic acid production from agro wastes using Lactobacillus delbrueckii," Process Biochemistry, vol. 41, no. 4, pp. 759-763, 2006.

[11] B. Djeghri-Hocine, M. Boukhemis, N. Zidoune, and A. Amrane, "Growth of lactic acid bacteria on oilseed crop pea- and chickpea-based media," World Journal of Microbiology and Biotechnology, vol. 23, no. 6, pp. 765-769, 2007.

[12] P. Burns, G. Vinderola, F. Molinari, and J. Reinheimer, "Suitability of whey and buttermilk for the growth and frozen storage of probiotic lactobacilli," International Journal of Dairy Technology, vol. 61, no. 2, pp. 156-164, 2008.

[13] L. Yu, T. Lei, X. Ren, X. Pei, and Y. Feng, "Response surface optimization of 1-(+)-lactic acid production using corn steep liquor as an alternative nitrogen source by Lactobacillus rhamnosus CGMCC 1466," Biochemical Engineering Journal, vol. 39, no. 3, pp. 496-502, 2008.

[14] F. ZhenHua, "Comparison of pineapple peel juice and MRS used as culture media for lactic acid bacteria," Modern Food Science and Technology, vol. 25, pp. 1416-1418, 2009.

[15] M. Krzywonos and T. Eberhard, "High density process to cultivate Lactobacillus plantarum biomass using wheat stillage and sugar beet molasses," Electronic Journal of Biotechnology, vol. 14, p. 6, 2011.

[16] S. A. Hayek, A. Shahbazi, S. S. Awaisheh, N. P. Shah, and S. A. Ibrahim, "Sweet potatoes as a basic component in developing a medium for the cultivation of lactobacilli,"
Bioscience, Biotechnology, and Biochemistry, vol. 77, no. 11, pp. 2248-2254, 2013.

[17] Y. Zhao, Y. Wang, Z. Song, C. Shan, R. Zhu, and F. Liu, "Development of a simple, low-cost and eurytopic medium based on Pleurotus eryngii for lactic acid bacteria," $A M B$ Express, vol. 6, p. 65, 2016.

[18] H. Almansour, T. Alonaizi, M. Kishk et al., "Cost-effective media for production of lactic acid bacteria isolated from poultry in Kuwait," International Journal of Poultry Science, vol. 18, no. 12, pp. 598-603, 2019.

[19] C. M. B. K. Muyanja, J. A. Narvhus, J. Treimo, and T. Langsrud, "Isolation, characterisation and identification of lactic acid bacteria from bushera: a Ugandan traditional fermented beverage," International Journal of Food Microbiology, vol. 80, no. 3, pp. 201-210, 2003.

[20] I. M. Mukisa, D. Porcellato, Y. B. Byaruhanga et al., "The dominant microbial community associated with fermentation of Obushera (sorghum and millet beverages) determined by culture-dependent and culture-independent methods," International Journal of Food Microbiology, vol. 160, no. 1, pp. 1-10, 2012.

[21] S. Byakika, Evaluation of Sorghum Malt as Growth and Carrier Medium for Lactobacillus Plantarum MNC 21 Biomass, Makerere University, Kampala, Uganda, 2015.

[22] M. C. De Vries, E. E. Vaughan, M. Kleerebezem, and W. M. de Vos, "Lactobacillus plantarum-survival, functional and potential probiotic properties in the human intestinal tract," International Dairy Journal, vol. 16, no. 9, pp. 1018-1028, 2006.

[23] I. M. Mukisa, Sensory Characteristics, Microbial Diversity and Starter Culture Development for Obushera, A Traditional Cereal Fermented Beverage, Kampala, Uganda, 2012.

[24] J. Taylor, "Guide to floor malting of sorghum and millets," 2008, http://digitalcommons.unl.edu/cgi/viewcontent.cgi? article $=1026 \&$ context $=$ intsormilpubs.

[25] I. Arana, M. Orruño, and I. Barcina, How to Solve Practical Aspects of Microbiology, Determination of the Parameters Defining the Bacterial Growth, Spain, 2013.

[26] AOAC, Association of Official Analytical Chemists, Official Methods of Analysis, Association of Official Analytical Chemists, The Association vol II, Arlington, Virginia, 1990.

[27] European Brewery Convention, "Ninhydrin colometric method (Method 8.8.7)," Analytica-EBCp. 141, 4th edition, Brauerrei- und Getranke-Rundschau, Zurich, Switzerland, 1987.

[28] S. Krishnaveni, T. Balasubramanian, and S. Sadasivam, "Sugar distribution in sweet stalk sorghum," Food Chemistry, vol. 15, pp. 229-232, 1984.

[29] K. Hayakawa, H. Sansawa, T. Nagamune, and I. Endo, "High density culture of Lactobacillus casei by a cross-flow culture method based on kinetic properties of the microorganism," Journal of Fermentation and Bioengineering, vol. 70, no. 6, pp. 404-408, 1990.

[30] C. F. Mignone and C. Avignone-Rossa, "Analysis of glucose carbon fluxes in continuous cultures of Bacillus thuringiensis," Applied Microbiology and Biotechnology, vol. 46, no. 1, pp. 78-84, 1996.

[31] R. Anderson and K. Jayaraman, "Influence of carbon and nitrogen sources on the growth and sporulation of Bacillus thuringiensis var Galleriae for biopesticide production," Chemical and Biochemical Engineering Quarterly, vol. 17, pp. 225-232, 2003.

[32] P. Saman, P. Fuciños, J. A. Vázquez, and S. S. Pandiella, "Fermentability of brown rice and rice bran for growth of 
human Lactobacillus plantarum NCIMB 8826," Food Technology and Biotechnology, vol. 49, pp. 128-132, 2011.

[33] F. Leroy and L. De Vuyst, "Growth of the bacteriocin-ProducingLactobacillus sakei strain CTC 494 in MRS broth is strongly reduced due to nutrient exhaustion: a nutrient depletion model for the growth of lactic acid bacteria," Applied and Environmental Microbiology, vol. 67, no. 10, pp. 44074413, 2001.

[34] K. C. Thomas and W. M. Ingledew, "Fuel alcohol production: effects of free amino nitrogen on fermentation of very-highgravity wheat mashes," Applied and Environmental Microbiology, vol. 56, no. 7, pp. 2046-2050, 1990.

[35] F. M. Saguir, I. E. Loto Campos, and M. C. Manca de Nadra, "Utilization of amino acids and dipeptides by Lactobacillus plantarum from orange in nutritionally stressed conditions," Journal of Applied Microbiology, vol. 104, no. 6, pp. 1597-1604, 2008.

[36] A. Tabula, Role of Alkali Treatment and Radical Removal in the Quality of Sorghum Malt and Obushera, Makerere University, Kampala, Uganda, 2015.

[37] A. M. Dallagnol, M. Pescuma, G. F. De Valdez, and G. Rollán, "Fermentation of quinoa and wheat slurries by Lactobacillus plantarum CRL 778: proteolytic activity," Applied Microbiology and Biotechnology, vol. 97, no. 7, pp. 3129-3140, 2013.

[38] E. Giraud, A. Champailler, and M. Raimbault, "Degradation of raw starch by a wild amylolytic strain of Lactobacillus plantarum," Applied and Environmental Microbiology, vol. 60, no. 12, pp. 4319-4323, 1994.

[39] E. Henshaw and I. Ikpoh, "Effect of single bacterial starter culture on odour reduction during controlled fermentation of cassava tubers for foofoo production," Mallaysian Journal of Microbiology, vol. 6, pp. 57-61, 2010.

[40] Neogen Corporation, "Lactobacilli MRS broth (7406)," 2010, http://www.neogen.com/Acumedia/pdf/ProdInfo/7406_PI. pdf.

[41] I. Marklinder and L. Johansson, "Sour dough fermentation of barley flours with varied content of mixed-linked $(1 \longrightarrow 3)$, $(1 \longrightarrow 4) \quad \beta$-d-glucans," Food Microbiology, vol. 12, pp. 363-371, 1995.

[42] E. Giraud, B. Lelong, and M. Raimbault, "Influence of $\mathrm{pH}$ and initial lactate concentration on the growth of Lactobacillus plantarum," Applied Microbiology and Biotechnology, vol. 36, no. 1, pp. 96-99, 1991.

[43] F. V. Passos, H. P. Fleming, D. F. Ollis, R. M. Felder, and R. F. McFeeters, "Kinetics and modeling of lactic acid production by Lactobacillus plantarum," Applied and Environmental Microbiology, vol. 60, no. 7, pp. 2627-2636, 1994. 